\title{
Н.В. ТРИШИНА
}

\section{ЭТИЧЕСКАЯ НАПРАВЛЕННОСТЬ «ТЕАТРАЛЬНОЙ ПРАКТИКИ» ЛЬВА ТОЛСТОГО}

\section{Надежда Владиславовна Тришина, \\ Российский институт театрального искусства (ГИТИС), кафредра истории театра России, \\ аспирант, \\ Малый Кисловский пер., д. 6, Москва, 125009, Россия \\ E-mail: bazumka@gmail.com}

Реферат. В статье исследуется характер деятельности Л.Н. Толстого в контексте современной писателю театральной жизни. Предпринята попытка создания образа Толстого как театрального деятеля своего времени - в противовес привычному образу гонителя театрального искусства. Определяется степень важности проблемы актерства в частной и общественной жизни писателя, анализируется диалектика его зрительских предпочтений и требований к искусству. Лев Толстой рассматривается как соавтор актерского образа, непосредственный создатель спектакля. Выявлен главнейший для Толстого угол зрения на цели искусства, в том числе и искусства театра, - этический. Только в таком контексте снимаются кажущиеся противоречия отношений Льва Толстого и театра. С помощью источников проанализированы особенности этических требований писателя к театру, актерскому искусству, режиссерской трактовке его пьес. Толстому важно, итобы зрители увидели и осознали в спектакле именно ту идею, которую драматург вкладывал в пьесу. Изменить жизнь частного человека, направить его к достижению христианского идеала - центральная идея Толстого.

Ключевые слова: Л.Н. Толстой как актер, Л.Н. Толстой как зритель, Л.Н. Толстой как соавтор спектакля, «Власть тьмы», «Плоды Просвещения», Малый театр XIX века.

Для цитирования: Тришина Н.В. Этическая направленность «театральной практики» Льва Толстого // Обсерватория культуры. 2016. Т. 13, № 3. C. $348-355$.

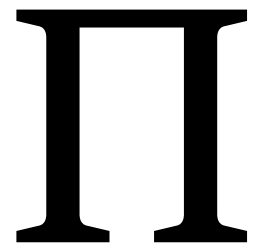

од словосочетанием «театр Льва Толстого» в современном театроведении подразумевается прежде всего драматургия Л.Н. Толстого. Изучением этой темы занимались такие исследователи, как К.Н. Ломунов [1], Е.И. Полякова [2] и др. Б.Ф. Сушков в своей работе «Уроки театра Толстого» [3] рассматривает проблему «театра Льва Толстого» как сценическую историю постановки пьес, уделяя пристальное внимание их идейно-нравственному содержанию.

В настоящей статье исследуется проблема участия частного человека - Льва Толстого - в современной ему театральной жизни, и поэтому понятие 
«театр Льва Толстого» приобретает новый смысл, связанный не столько с созданной писателем драматургией, сколько с попыткой осмысления личностных связей Толстого с институтом театра. Подробного изучения этой проблемы в театроведении ранее не проводилось. Эта статья - часть исследовательской работы «Театр в этической системе Льва Толстого».

\section{ТОЛСТОЙ - АКТЕР}

$\mathrm{H}$ а сценические подмостки Л.Н. Толстой выходил только в студенчестве. Обучаясь на первом курсе Казанского университета, писатель участвовал в любительских спектаклях и «живых картинах». Это были «благородные спектакли», устраиваемые любителями в благотворительных целях.

Нечастые театральные выступления Толстого отмечались в «Казанских губернских ведомостях». Например, в номере 11 за 1845 г. в статье «Благородный театр» читаем: «Толстой выполнил свою роль так отчетливо, так прелестно, что во многих местах зрители забывали, что перед ними сценическое искусство, а не сама природа» [4, с. 15]. К сожалению, что именно за роль исполнял Лев Николаевич, в статье не упоминается. В другом выпуске газеты отмечено его выступление в «живой картине» в роли Жениха: «Оркестр играет: "Ну, Карлуша, не робей”... Старик-рыбак поймал в свои сети молодца и представляет его своей дочери. Простакдетина (граф Л.Н. Толстой) почтительно вытянулся, закинув руки за спину: он рисуется... Отец взял его за подбородок и с простодушно-хитрою улыбкой посматривает на дочку, которая в смущении потупила свои взоры. Эффект этой картины был необычайный, - раза три требовали ее повторения, и долго не умолкал гром рукоплесканий. Лучше всего был в этой картине А.А. де Планьи (лектор французского языка), чрезвычайно наивен был также и жених - граф Л.Н. Толстой» [5, с. 572].

Эти несколько строк в двух газетах - единственная информация о Толстом, выходившем на сцену в качестве исполнителя театральной роли. Вместе с тем нельзя сказать, что этим ограничивается актерская деятельность, или шире - актерство Льва Толстого.

До конца своих дней Л.Н. Толстой имел удивительную способность мгновенно перевоплотиться из одного образа в другой, предстать перед людьми другим человеком, совсем не тем, что был минуту назад. Подобные воспоминания сохранились в мемуарах многих современников писателя. Например, П.П. Гнедич пишет, как Толстой разговаривал с ним о духоборах, сектантах, в переселении которых Лев Николаевич принимал активное участие; перед слу- шателем в этот момент возникал «юноша-утопист, который верит в обновление жизни и в райское житье среди прерий» [6, с. 176].

Великий писатель мог заплакать перед собеседником от избытка чувств, как, например, это случилось во время разговора о судьбе духоборов: «Несколько раз он наскоро вытирал глаза, сверкавшие ярким светом из-под нависших бровей. Слезливые нотки все чаще прорывались у него. Потом он бросил письмо и сказал: "Простите, не могу! Волнует это меня” [6, с. 176]. Но когда уже через минуту после этого события в комнату к Толстому вошли светские люди, которые искали младших членов его семьи, совсем иной Лев Николаевич ответил им: «Никого нет, подождите, они скоро будут» [6, c. 177]. Толстой, по словам Гнедича, за секунду превратился в светского человека, хоть и одетого в блузу, но «графа, представителя общества: старого графа Курагина - не какого-то прокурора Ивана Ильича или профессора Кругосветлова - а старого, исконного русского аристократа» [6, с. 177].

М. Горький вспоминает, как Лев Николаевич умел понравиться, если ему это было нужно, и также подчеркивает, как артистически он умел перевоплощаться из одного образа в другой - в зависимости от того, с кем он разговаривает. Мужицкая борода, простая одежда, грубые, но необыкновенные руки и «весь этот внешний, удобный демократизм обманывал многих» [7, с. 286].

Часто люди, привыкшие встречать человека по одежке, начинали обращаться со Львом Николаевичем излишне фамильярно, бесцеремонно: «Ах, родной ты наш! Вот какой ты! Наконец-то сподобился я лицезреть величайшего сына земли родной моей. Здравствуй вовеки и прими поклон мой!» [7, с. 286]. Так проявлялось обращение «московско-русских», а были еще и другие собеседники, как называет их Горький, «свободномыслящие» [7, с. 286]. «Лев Николаевич! Будучи не согласен с вашими религиозно-философскими взглядами, но глубоко почитая в лице вашем великого художника...» [7, с. 286]. Горький описывает, как в этот момент из-под мужицкой бороды, из-под демократической мятой блузы возникает старый русский барин, великолепный аристократ, с благородными и грациозными жестами, гордой сдержанностью речи - «тогда у людей прямодушных, образованных и прочих сразу синеют носы от нестерпимого холода. Барина в нем было как раз столько, сколько нужно для холопов. И когда они вызывали в Толстом барина, он являлся легко, свободно и давил их так, что они только ежились и попискивали» [7, с. 286].

Уже из этих нескольких примеров (а рассказать подобных ситуаций можно множество) мы видим, что сам Лев Николаевич до конца жизни был актером, могущим в минуту перевоплотиться, умеющим произвести впечатление. «Уход» и последу- 
ющая за ним смерть писателя стали, вопреки воле Толстого, грандиозным спектаклем, в котором ему принадлежала главная роль, а зрителем был практически весь мир. Мир, который он изо всех сил пытался изменить к лучшему. В этом стремлении, на наш взгляд, и заключается разгадка отношения Толстого к театру.

\section{ТОЛСТОЙ - ЗРИТЕЛЬ}

$\mathrm{T}$ Театральные вкусы Л.Н. Толстого формируются в Казани. Здесь Толстому-студенту посчастливилось увидеть Мартынова в роли Хлестакова - актер никогда не любил этот образ и редко с ним выступал. Впоследствии писатель будет говорить, что Мартынов - это лучший русский актер, которого он видел [8, с. 197]. Помимо Мартынова, Щепкин и Мочалов производят на Толстого глубокое впечатление.

Позже, уже в Москве, Толстой познакомится с Островским и вскоре перейдет с ним «на ты». Видимо, именно Островский влияет на Толстого в том смысле, что Лев Николаевич начинает разделять актеров на две категории: «по слуху» и «с глазу»: «актер “по слуху” ищет характер лица в самой речи и обыкновенно играет вернее, а актер “с глазу” - эффектнее» [9, с. 2].

Таким образом, можно заключить, что исполнительская школа Малого театра была Толстому ближе, нежели Александринского. Толстой становится частым закулисным гостем Малого театра. Вместе с тем в его дневниках нет подробных описаний театральной жизни, лишь - короткие упоминания.

В 1857 г. Толстой уезжает за границу; его парижский дневник наполнен театральными впечатлениями. За три месяца он побывал (и иногда не по одному разу) практически во всех парижских театрах, начиная от самых известных и заканчивая маленькими бульварными театриками и цирком. Особенно Лев Николаевич оценил «Комеди Франсэз», или «Дом Мольера». Здесь он видел спектакли «Скупой», «Лекарь поневоле», «Смешные жеманницы», «Мнимый больной» Ж.-Б.Мольера и «Женитьбу Фигаро» П. Бомарше. В статье «Что такое искусство», написанной через 40 лет, Толстой высоко оценит творчество Мольера. В то же время комедию Ж. Расина «Тяжущиеся» он позже назовет «дрянью» [5, с. 572].

По приезду из-за границы Толстой переживает внутренний кризис, вследствие которого переезжает жить в Ясную Поляну, подальше от столиц. Там он начинает усиленно заниматься школьной деятельностью, уже не так увлеченно следит за литературно-театральной жизнью.

В 1862 г., после женитьбы на С.А. Берс, Толстой все реже выбирается в Москву. Но когда по разным делам ему все-таки случалось попасть в Москву, он посещал и театр. Спектакль по пьесе «Грех да беда на кого не живет» А.Н. Островского производит на Толстого огромное впечатление. Вообще, позже он назовет Островского гениальным драматическим писателем, но добавит, что «он не произведет ничего вполне гениального, потому что сознание своей гениальности у него перешло свои границы» [5, с. 572].

Отношение к пьесам Островского характеризует и отношение Толстого к театральному искусству вообще, которое позже отразится в статьях «Что такое искусство?» и «О Шекспире и о драме». Так, например, исторические пьесы Островского Толстой не любил. Спектакль по пьесе «Тушино» в ноябре 1867 г. Лев Николаевич даже не досмотрел до конца - так ему не понравилось.

Став знаменитым писателем, Лев Николаевич старается если и появляться в театре, то следить за действием из-за сцены. С.А. Попов рассказывал, как Толстой смотрел спектакли из первой кулисы. «Выбирал он пустячные комедии и, глядя на спектакль, искренно смеялся и веселился, утверждая, что такие пьесы куда приятнее смотреть, чем серьезные» [10, с. 432].

Поведение Толстого на спектакле было главным показателем, понравилось ему представление или нет. Хохочет он до слез или хмурит брови - весь театр следит за его реакцией. Когда Толстой пришел на «Дядю Ваню» в МХТ, всем наблюдающим за ним во время спектакля казалось, что действие вовлекало его в свою атмосферу, что внимание великого писателя было приковано к происходящему на сцене, и даже что местами он был растроган. Но, по признанию одного из таких «наблюдателей», Вл. И. Немировича-Данченко, или «мы ошибались, или он отстранял от самого себя простую, непосредственную восприимчивость, потому что в антрактах он ничего не хвалил. Правда, ничего не порицал, словно дожидаясь, чем все это кончится» [11, с. 226-227]. Известно, что после окончания спектакля Толстой недоумевал и неодобрительно кивал головой: «Чего ему еще нужно (Астрову)? Тепло, играет гитара, славно трещит сверчок. А он сначала хотел взять чужую жену, теперь о чем-то мечтает...» [11, с. 227].

Толстой умел разделять, что именно ему нравится или не нравится в постановке: пьеса, ее понимание режиссером или актерская игра. Так, в том же «Дяде Ване» он высоко оценивал технику исполнения, но ему казалось, что техника убивала внутреннее содержание. «В “Дяде Ване” Толстой находит недочет в нравственном смысле пьесы», пишет интервьюер Толстого Николай Энгельгардт в 1900 г. [12, с. 66].

Хотя в целом спектакль Малого театра «Плоды Просвещения» не понравился Льву Николаевичу, он выделяет отдельных исполнителей, хорошо справившихся со своей задачей. Больше всех произвел на него впечатление А.П. Ленский, исполняющий роль Кругосветлова. «Много комплиментов выпало 
на долю этого артиста», - вспоминает П.М. Пчельников [6, с. 179]. Н.И. Музиль так исполнил монолог старого повара, что Толстой удивился, произнеся: «Странно, почему это цензура не вычеркнула эту сцену!» [6, с. 179]. Отметил Толстой и О.О. Садовскую, которая играла кухарку, понравилась ему и Таня в исполнении Турчаниновой. В своей героине она представляла зрителям русскую девушку, а не «мольеровскую субретку». Все замечания писателя по поводу создания образа персонажей его пьес воспринимались актерами с интересом.

Само появление Толстого в театре в день спектакля «Плоды Просвещения» было большим событием для всех исполнителей. Г.Н. Федотова, например, не зная, как выразить свою радость по поводу появления Толстого за кулисами, «бросилась к нему на шею, расцеловала его, потом и сына его Сергея» [13, с. 8-9].

Будучи в театре не самым частым гостем, Толстой все-таки следил за главными театральными событиями. Так, когда актер Давыдов ${ }^{1}$ пришел к Льву Николаевичу за разрешением прочесть «Власть тьмы» на студенческом вечере, он встретил его со словами: «Очень рад вас видеть. Покажитесь-ка, какой вы революционер!» [14, с. 43]. Слово «революционер» Толстой употребил в том смысле, что Давыдов на тот момент недавно оставил сцену императорского театра и перешел к Коршу. Тогда об этом говорили, как о протесте со стороны артиста, желающего играть более серьезные роли и готовиться к ним большее время. И об этом театральном событии Толстой, судя по его словам, знал.

Во время чтения Давыдовым сцен «Власти тьмы» Лев Николаевич устроил актера перед диваном, поставил перед ним маленький стол, а сам сел на диван. Сначала Давыдов слышал поддакивания и одобрительные «Гм, гм!», когда же артист дошел до сцены, где Никита впервые ужасается совершенному им, Давыдов случайно взглянул на автора пьесы. По «сурово-мнимому лицу Льва Николаевича катились слезы. В одном месте он даже всхлипнул» [14, с. 43]. После этого чтения Толстой хвалил Акима, Матрену, Анютку в исполнении Давыдова, но Митрич ему не понравился. Толстой подчеркивал, что Митрич отличается от остальных героев пьесы: он был солдатом, жил в городах, и поэтому у него другая манера говорить, другое понимание жизни, нежели у деревенских людей. И когда Давыдов попросил Льва Николаевича показать, как надо читать Митрича, Толстой взял книгу и начал читать так просто, «что даже не чувствовалось чтения, а казалось, что говорит сам Митрич» [14, с. 45]. Лев Николаевич своим тоном, манерой речи передал Давыдову суть образа. Актер признается, что ему сразу стало понятно, как надо читать Митрича, и какая разница между ним и Акимом, Петром и другими.
Толстого как зрителя всегда отличала чуткость, внимательность. Именно благодаря этим качествам писатель был способен дать актерам такие советы, которые способствовали рождению интересных и точных театральных образов.

\section{ТОЛСТОЙ - СОАВТОР АКТЕРСКОГО ОБРАЗА}

$\mathrm{T}$ олстой не раз помогал актерам в создании образов, подсказывал штрихи к роли. Так, например, в переписке с М.Г. Савиной, которая через князя Оболенского просит разрешить его поставить в свой бенефис на сцене Александринского театра «Власть тьмы», он говорит о выбранном ею образе Акулины: «Ее речи туповаты, пошлы даже, но ее движения, ее фигура всегда строго, грациозно величавы» [15, с. 141]. Лев Николаевич также выражает сожаление актрисе, что, по его словам, мало обработал роль Акулины. Но тут же говорит о способности даровитых актеров, к которым он, безусловно, причисляет собеседницу, «из ничего делать многое» [15, с. 140]. Он пишет: «Я понимаю эту женщину, Акулину, так: дурковатая (т. е. умственная машина действует в ней хоть и правильно, но медленно), добрая, прямая, даже честная и великодушная по природе, но по своему развитию ближе к животному, чем к человеку» [15, с. 140].

Важное замечание делает Толстой о значении образа Акулины в пьесе: «Не хорошо бывает, когда выдающийся актер берет второстепенную по смыслу роль и тем путает les valeurs (значение. - H.T.) ролей. Но тут будет наоборот: роль Акулины, небольшая по размерам, должна иметь первостепенное значение» [15, с. 140], - пишет он Савиной.

Но в 1887 г. «Власть тьмы» была все-таки запрещена, и Савина тогда не сыграла эту роль. И только в 1895 г., когда пьесу наконец-то допустили к постановке на сцене, Толстой сам прочитает пьесу труппе Малого театра. В. Рыжова так вспоминает об этом: «Чтение происходило в конторе театров на Большой Дмитровке. Собралась почти вся труппа и чувствовалась во всех какая-то приподнятость, торжественность. Мы будем слушать и разговаривать с великим творцом “Детства”, “Войны и мира”, “Анны Карениной”. И вот он вошел - скромный, с какой-то тихой, стыдливой улыбкой на лице, и эта простота и скромность еще больше возвысили его в наших глазах. С первых же слов, прочитанных им, так ярко и так сочно стали вставать перед нами образы действующих лиц, а сцена Анютки с Митричем произвели на нас прямо потрясающее впечатление. Мы сидели ошеломленные, очарованные его чтением. Исключительно он читал Акима - это знаменитое “тае” Акима он так разнообразно и так удивительно говорил, что в этом “тае” читались целые глубокие мысли» [16]. 
Позже Рыжова будет говорить о гениальности Толстого как чтеца. «Исключительное богатство интонаций, необыкновенная простота и образность речи, четкость, с которой он вычерчивал характеры живых, настоящих крестьян» [16], поражают всю труппу Малого театра.

Кроме того, что Лев Николаевич читал пьесу труппе, он присутствовал на репетициях спектакля. В целом свидетели отмечают, что Толстой всегда както незаметно, не привлекая к себе внимания, приходил на репетиции, в своей блузе и башлыке, тихонько пробирался в темный зрительный зал. Но хотя образ, который создавал он в театре, был чуть ли не образ конфузливого человека, это не помешало Льву Николаевичу на одной из репетиций в какой-то момент подняться со своего места в зрительном зале и отправиться за кулисы [16]. Там он начал спор с постановщиком по поводу некоторых мизансцен, которые были, с его точки зрения, построены неверно. Для Толстого было чрезвычайно важно донести мысль, идею своей пьесы до зрителя. Иначе, по Толстому, постановка спектакля была бы бессмысленным делом. Замечания автора пьесы всегда были яркими, глубокими, порой даже неожиданными. Говоря о роли Акулины, Толстой подчеркивал, что она должна была исполниться тупой и грубой, с почти звериной жестокостью, которая была следствием «придушенной атмосферы темноты и забитости» [16].

В спектакле, который в целом не понравился Толстому, он отмечал В.Н. Рыжову - Акулину, которая «давала настоящую деревенскую девку» [16]. Понравилась ему и исполнительница роли Матрены О.О. Садовская. Он считал, что только она поняла истинный характер этой трудной роли. По Толстому, Матрена - вовсе не злодейка и не тульская леди Макбет. «Матрена - обыкновенная старуха, умная, деловитая, желающая по-своему добра сыну. Ее поступки - вовсе не результат каких-то особенных злодейских свойств ее характера. Это просто выражение ее миросозерцания, где добро и зло совершенно смешаны. Она не научилась их различать. Темные дела делаются, по ее мнению, всеми, без всякого исключения. Она этого не боится, только чтоб не было зазорно и непристойно» [9, с. 2], - так говорил писатель.

Толстой ведет активную переписку с актерами и постановщиками «Власти тьмы», отвечает на письма, телеграммы: как говорить - «тае» или «таё»? (спрашивает П.М. Свободин) [17, с. 100], какими должны быть декорации? [17, с. 40], в чем должны быть одеты актеры? [18]. На все вопросы Лев Николаевич дает подробные разъяснения, советы.

Также он участвовал и в процессе подготовки спектакля «Власть тьмы» в МХТ. «Внимательно консультирует он не только постановщиков и режиссеров «Власти тьмы» в Художественном театре, но даже машинистов сцены, готовящих эту постановку. $<. .>$ Толстой входил до мелочей во все, касающее- ся постановки... отстаивал каждую дверь, указывая окно, отмечая, где стоять стулу или скамейке» $[17$, c. 40]. Но на спектакле Лев Николаевич не был. Однако это не значит, что он не знал, как «Власть тьмы» была поставлены. Как-то раз в разговоре с Вл.И. Немировичем-Данченко Толстой сказал ему о неуместности разных натуралистических звуков в спектакле. Владимир Иванович пишет, что тогда он «должен был со всей любезностью и покорностью сказать ему (Толстому. - H.T.), что у него самого в экземпляре значится: «Слышно ржание лошадей», «Слышно, как закрывается калитка» и т. д. [11, с. 228].

Единственным спектаклем «Власть тьмы», который одобрил Толстой, было представление театра «Скоморох». С этим театром Толстого связывали особые отношения. Еще в 1886 г. он получил письмо от М.В. Лентовского, в котором антрепренер, задумавший создать народный театр «Скоморох», просит у Льва Николаевича «нравственной поддержки для своего измученного сердца» [19, c. 228]. Именно это письмо стало толчком к написанию «Власти тьмы». В «Скоморохе» состоялась бы его московская премьера, если бы пьесу разрешили тогда, в 1886 году. В 1895 г., когда пьесу сняли из-под запрета, «Власть тьмы» была сыграна и в «Скоморохе». Толстой присутствовал на этом спектакле в райке, инкогнито, одевшись в полушубок, валенки и войлочную шапку. Спектаклем он остался доволен.

Говоря об отношении Толстого с народными театрами, необходимо вспомнить, что Лев Николаевич был очень обрадован, получив в начале 1886 г. письмо от П.А. Денисенко, издававшего в то время журнал «Дневник русского актера». В письме Денисенко просит разрешения переделать в драматическую форму рассказы Толстого. Писатель не только дает согласие на переделку своих прозаических вещей в пьесы, но и обещает сам написать драматическое произведение для народного театра. «Дело, занимающее вас - народный театр, - пишет Толстой, - занимает и меня. И я был бы очень рад, если бы мог ему содействовать» [20, с. 98]. Он просит Денисенко отдаться делу народного театра «не раздумывая, не готовясь прямо, перекрестясь, прыгать в воду»; т. е. переделывать, переводить, собирать пьесы, «которые имели бы глубокое вечное содержание и были бы доступны всей той публике, которая ходит в балаганы» [20, с. 98].

Много позже, летом 1910 г., к Льву Николаевичу в Ясную Поляну приезжает актер П.Н. Орленев, о котором за месяц до этого Чертков пишет Толстому: «Актерское "ремесло" никогда его не удовлетворяло, и он постоянно лелеял мечту, что когда-нибудь ему удастся поделиться своим искусством с простым народом» [21]. Лев Николаевич при встрече с Орленевым буквально забрасывает актера вопросами о крестьянском театре: о содержании народных пьес, 
восприятии их зрителями. В ответ на все вопросы «Орленев стал вести театрализованный рассказ содержания пьесы, с необычайным искусством проигрывая роли каждого из действующих лиц. Не забывал он показывать и то, как воспринимают пьесу крестьяне» [21]. Рассказ очень понравился Толстому.

Льву Николаевичу было близко и творчество актера В.Н. Андреева-Бурлака, в особенности его чтецкие выступления. Летом 1886 г. С.А. Толстая запишет в своем дневнике о выступлении перед их семьей Андреева-Бурлака: «Рассказы были удивительно хороши, и Левочка (Л.Н. Толстой. - H.T.) смеялся так, что нам с Левой (сыном. - Н.T.) стало жутко» [22, с. 262].

Биограф Андреева-Бурлака С. Нельс пишет о том вечере: «Бурлак был в ударе. Ободренный вниманием Толстого, он читает и рассказывает так же естественно, как всегда. Импровизации следуют одна за другой. Замечательно читает он рассказ Мармеладова» [22, с. 262]. Именно Андреев-Бурлак во время одного из экспромтов расскажет историю о разговоре в купе вагона, в котором человек признается, как убил жену из ревности; этот сюжет позже послужит зародышем «Крейцеровой сонаты».

Первоначально повесть была задумана как рассказ, который Андреев-Бурлак прочел бы с эстрады и к которому Репин написал бы картину, экспонирующуюся во время чтения. Толстой хотел изобрести такой новый жанр театрального представления, «в котором на зрителя подействовали бы одновременно мастерство художника слова, актера и живописца» $[17$, с. 54]. Замыслу этому не суждено было совершиться: вскоре Андреев-Бурлак умер.

Можно предположить, что в 1880-1890-е гг., т. е. уже после перелома в мировоззрении, Толстой все еще активно участвует в театральной жизни. С другой стороны, в 1895 г., когда «Власть тьмы» была допущена цензурой к представлению, в интервью газете «Курьер торговли и промышленности» писатель говорит о том, что ничего не может сказать об исполнении пьесы в Малом театре по той причине, что «не бывает в театре уже около тридцати лет» [12, с. 61]. Мы понимаем, что Лев Николаевич явно лукавит в этом ответе. Пусть он не частый театральный зритель, но уж о том, как ставятся его пьесы, он был осведомлен.

Нам известно, с каким уважением Толстой всегда относился к своему собеседнику, да и вообще к любому человеку. Вероятно, своими словами о том, что тридцать лет не бывает в театре, Толстой поначалу хотел скрыть от собеседника свое истинное отношение к спектаклю: он искренне не хотел обидеть участников «Власти тьмы». Но все-таки в дальнейшем разговоре не смог удержаться от рекомендаций, раскрывающих его взгляд на то, какими должны предстать персонажи пьесы перед зрителями.

Толстой признается, что все его указания артистам, которые он каким-либо образом давал, - «это просто советы» [12, с. 61]. В этом интервью мы видим Льва Николаевича, с одной стороны, не желающим оскорбить или обидеть кого-либо из участников спектакля, с другой - стремящимся донести истинный смысл пьесы до зрителей. Писатель говорит, что, судя по отзывам и рецензиям, ни один из артистов не исполняет роль Акима так, как задумал автор. Толстого не устраивает, что Акима играют серьезным проповедником. Лев Николаевич считает, что этот персонаж должен представать перед зрителем суетливым, вечно волнующимся, он «всегда красный от пронимающего его волнения, беспомощно хлопает себя руками, качает головой, часто повторяет свое «тае-тае» [12, с. 61]. Он хотел бы, чтобы Аким выглядел перед публикой смешным. Зрителю поначалу должно показаться, что Аким ничего не стоящий человек, ведь его не уважают ни собственный сын, ни жена. Его заикание усиливает комичность образа. Но вот настает момент, и Аким раскрывает свою душу, в ней обнаруживаются такие глубины, что каждому зрителю «должно сделаться жутко» [12, с. 61]. Вместе с тем Лев Николаевич тут же оговаривается, что исполнить эту роль по его совету действительно сложно, ведь актер «мог бы вдруг чем-нибудь вызвать смех и в самый трагический момент, и для него все бы пропало, а мне, автору, было бы все равно» [12, с. 61].

В этом же интервью Толстой даст советы исполнителям роли Никиты: автор советует не изображать его ни Дон Жуаном, ни героем. Никита, по Толстому, самый обыкновенный крестьянский парень, такой есть в каждой деревне. Его несчастье состоит «в бесхарактерности и нравственном шатании» [12, с. 62]. «Артисты должны держать себя как можно проще, приложив все старания к толковой и правильной передаче своих слов» [12, с. 61]. В целом, Толстой дает совет всем артистам: как можно меньше стараться что-то изображать в пьесе. Он призывает их обратить внимание на крестьян: внешнее проявление чувств у них заметить сложно, они все скрывают в своей душе.

Все эти мысли, напомним, были сказаны не в частной беседе, а опубликованы в газете и, конечно, служили бесценным советом исполнителям ролей. Толстой, безусловно, продолжал быть сотворцом спектакля - истолкователем своей пьесы, вдохновителем актерских образов.

Главным для Льва Николаевича было донести до сердца зрителя ту мысль, то чувство, которое способно будет заставить его задуматься над своей жизнью, изменить ее, направив к недостижимым христианским идеалам, объединить людей в этом стремлении.

Не находя ответа своим требованиям к искусству в современном ему театре, Толстой в статьях «Что такое искусство?» и «О Шекспире и о драме» решает вовсе упразднить театр в той форме, в которой он существует. Он выдвигает проект нового 
театра, подчас с неожиданными для его современников, но вполне логичными для самого Толстого критериями искусства.

\section{Примечание}

1 Позже именно он станет первым постановщиком «Власти тьмы»: в любительском театре Приселковых в Петербурге в январе 1890 года. На этот спектакль, официально запрещенный для императорской сцены, внезапно приехали Александр III с супругой и великими князьями. Все они не могли себе отказать в удовольствии увидеть постановку.

\section{Список источников}

1. Ломунов К.Н. Драматургия Л.Н. Толстого. Москва, $1956.467 \mathrm{c}$.

2. Полякова Е.И. Театр Льва Толстого: драматургия и опыты ее прочтения. Москва, 1978. 344 с.

3. Сушков Б.Ф. Уроки театра Толстого. Тула, 1983. 255 с.

4. Брянский А.И. Л.Н. Толстой - актер-любитель // Обозрение театров. 1910. № 1273. С. 14-15.

5. Гусев Н.Н. Толстой и театр // Современный театр. 1928. № 37. С. 572-573.

6. Гнедич П.П. Книга жизни. Воспоминания. 18551918. Москва, 2000. 365 с.

7. Горький М. Лев Толстой // Собр. соч. в 16 т. Т. 16. Очерки. Литературные портреты. Статьи. Москва, 1979. С. 253-300.

8. Маковицкий Д.П. У Толстого. 1904-1910 : (Из яснополянских записок) // Вопросы литературы. 1978. № 8 . С. $168-208$.
9. Николаев С. Л.Н. Толстой - зритель // Театральная декада. 1935. № 31. С. 1-2.

10. Бахрушин Ю.А. Воспоминания. Москва, 1994. 700 с.

11. Немирович-Данченко В.И. Из прошлого. Москва, 2003. $346 \mathrm{c.}$

12. Лакшин В Я. Лев Толстой дает интервью // Звезда. 1978. № 8. С. 57-81.

13. Старый Т. Лев Толстой на спектакле «Плоды Просвещения» // Театральная неделя. 1940. № 17(38). C. 8-9.

14. Давыдов В.Н. Из воспоминаний актера // Международный толстовский альманах. О Толстом. Москва, 1909. С. 42-47.

15. Степанова Г.И. Толстой и Савина : (неизвестное письмо Л.Н. Толстого) // Русская литература. 1967. № 2. C. $140-143$.

16. Рыжова В.Н. Толстой в Малом театре // Современный театр. 1928. № 37. С. 579.

17. Афанасьева Н.В. Театр глазами Толстого // Театр. 1960. № 11. С. $12-100$.

18. Благоволина Ю.П. Телеграмма Л.Н. Толстого к Н.Н. Макарову // Государственная библиотека СССР им. Ленина. Отдел рукописей. Вып. 39. Москва : Книга, 1987. С. 153.

19. Дмитриев Ю.А. Михаил Лентовский. Москва, 1978. 303 c.

20. Мишин В.И. Русские актеры в переписке с Л.Н. Толстым // Театр. 1960. № 11. С. 98-101.

21. Кошаев Х. П.Н. Орленев в Ясной Поляне // Театральная жизнь. 1960. № 17. С. 13.

22. Нельс С. М. Андреев-Бурлак. Москва, 1971. 288 с.

\section{ETHICAL ORIENTATION OF LEO TOLSTOY'S “THEATRICAL PRACTICES"}

\section{NADEZHDA V. TRISHINA,}

Russian University of Theatre Arts (GITIS), 6 Maly Kislovsky Lane, Moscow, 125009, Russia

E-mail: bazumka@gmail.com
Abstract. The article analyzes the specificity of Leo Tol- stoy's activities in the context of the theatrical life of his period. The author tries to represent Tolstoy as a theat- rical figure of his time - in contrast to his usual image of a persecutor of the dramatic art. The article explores the problem of dramatic art and its importance in the writ- er's private and social life; there are analyzed the dialec- tics of Tolstoy's spectator preferences and his requirements for the art. Leo Tolstoy is shown as a co-author of theat- rical image and a direct creator of performance. The au- thor of the article uncovers the most important for Tolstoy angle of view of any art's aims, including those of the dra-

matic art, - the ethical one. This context gives the opportunity to eliminate the seeming contradiction of relations between Tolstoy and the theatre. By analyzing the sources, the author explores the peculiarities of Tolstoy's ethical requirements for the theatre, dramatic art, and director's interpretations of his plays. It was important for Tolstoy to make the spectators understand the main idea which the dramatist had put into the play. To change the person's private life and to direct them in their attempts to achieve the Christian ideal was the main idea of Leo Tolstoy.

Key words: L.N. Tolstoy as an actor, L.N. Tolstoy as a spectator, L.N .Tolstoy as a co-author of the play, "The Power of Darkness", "Fruits of Enlightenment", the Maly Theatre of the 19th century.

Citation: Trishina N.V. Ethical Orientation of Leo Tolstoy's "Theatrical Practices", Observatory of Culture, 2016, vol. 13, no. 3, pp. 348-355.

\section{References}

1. Lomunov K.N. Dramaturgia Tolstogo [Dramaturgy of Tolstoy]. Moscow, 1956, $467 \mathrm{p}$. 
2. Polyakova E.I. Teatr L'va Tolstogo: dramaturgiya i opyty ee prochteniya [The Tolstoy Theatre: Dramaturgy and Experiences of its Reading]. Moscow, 1978, 344 p.

3. Sushkov B.F. Uroki teatra Tolstogo [The Lessons of Tolstoy Theatre]. Tula, 1983, $255 \mathrm{p}$.

4. Bryanskii A.I. L.N. Tolstoi - aktyor-lyubitel' [Tolstoy as Amateur Actor], Obozrenie teatrov [Review of Theatres], 1910, no. 1273 , pp. 14-15.

5. Gusev N.N. Tolstoi i teatr [Tolstoy and Theatre], Sovremennyj teatr [Contemporary Theatre], 1928, no. 37, pp. 572-573.

6. Gnedich P.P. Kniga zhizni. Vospominaniya 1855-1918 [Book of Life. Memories 1855-1918]. Moscow, 2000, $365 \mathrm{p}$.

7. Gor'kii M. Lev Tolstoi [Leo Tolstoy], Ocherki. Literaturnye portrety. Stat'i [Essays. Literature Portraits. Articles: Collected Works in 16 volumes, vol. 16]. Moscow, 1979, pp. 253-300.

8. Makovitskii D.P. U Tolstogo. 1904-1910 (Iz yasnopolyanskih zapisok) [At Tolstoy's 1904-1910: From Yasnaya Polyana Notes], Voprosy literatury [Questions of Literature], 1978, no. 8, pp. 168-208.

9. Nikolaev S. L.N. Tolstoj - zritel' [Tolstoy as a Spectator], Teatral'naya dekada [Theatre Decade], 1935, no. 31, pp. $1-2$.

10. Bakhrushin Yu.A. Vospominaniya [Memories]. Moscow, 1994, $700 \mathrm{p}$.

11. Nemirovich-Danchenko V.I. Iz proshlogo [From the Past]. Moscow, 2003, 346 p.

12. Lakshin V.Ya. Lev Tolstoi dayot interv'yu [Leo Tolstoy gives an Interview], Zvezda [Star], 1978, no. 8, pp. $57-81$.
13. Starii T. Lev Tolstoj na spektakle "Plodi Prosvesheniya” [Leo Tolstoy at the Performance "The Results of Enlightments"], Teatralnaya nedelya [Theatre Week], 1940, no. $17(38)$, pp. 8-9.

14. Davydov V. N. Iz vospominanij aktyora [From the Actor's Memories], Mezhdunarodnyi tolstovskij al'manah. O Tolstom [International Tolstoy's Almanac. About Tolstoy]. Moscow, 1909, pp. 42-47.

15. Stepanova G. I. Tolstoi i Savina (neizvestnoe pis'mo L.N. Tolstogo) [Tolstoy and Savina (unknown Tolstoy's Letter)], Russkaya literatura [Russian Literature], 1967, no. 2, pp. $140-143$.

16. Ryzhova V.N. Tolstoi v Malom teatre [Tolstoy in Maly Theatre], Sovremennyi teatr [Contemporary Theatre], 1928, no. 37, p. 579.

17. Afanas'eva N.V. Teatr glazami Tolstogo [The Theatre with Tolstoy's Eyes], Teatr [Theatre], 1960 , no. 11, pp. 12-100.

18. Blagovolina YU.P. Telegramma L.N. Tolstogo k N.N. Makarovu [The Tolstoy Telegram to Makarov], Gosudarstvennaya biblioteka SSSR im. Lenina. Otdel rukopisei [USSR Lenin State Library. The Department of Manuscripts]. Moscow, 1987, issue 39, p. 153.

19. Dmitriev Yu.A. Mikhail Lentovskii [Michael Lentovsky]. Moscow, 1978, 303 p.

20. Mishin V.I. Russkie aktyory v perepiske s L.N. Tolstym [Russian Actors in Communication with Tolstoy], Teatr [Theatre], 1960, no. 11, pp. 98-101.

21. Koshaev H. Orlenev P.N. v Yasnoj Polyane [Orlenev in Yasnaya Polyana], Teatral'naya zhizn' [Theatre Life], 1960, no. 17, p. 13.

22. Nel's S. Andreev-Burlak M. [Andreev-Burlak M.]. Moscow, 1971, $288 \mathrm{p}$. 